\title{
Enhancing Women Emancipation for Socioeconomic Transformation in and Beyond Nigeria
}

\author{
E. T. Salako, Ph.D. \\ National Teachers' Institiute \\ Department Of Social Studies Education, Nigeria.
}

\begin{abstract}
The persistence of unequal outcomes with the underutilisation of female abilities and restriction of individual opportunities has it concerns partly on socioeconomic transformation and national development. Tradition or culture and religion have dictated men and women relationship for centuries and entrenched male domination into the structure of social organization and institution at all levels of leadership. Even after several decades of massive economic and social change, inequality in socioeconomic outcomes still remains a significant issue. This development has raised several questions which remained largely unanswered and has equally attracted many gender-related studies and intellectual discourse on female liberation. Patriarchy justifies the marginalization of women in education, economy, labour market, politics, business, family, domestic matters and inheritance. This paper examined dimensions of gender inequality and discrimination that excludes women from socioeconomic and political activities. This is detrimental to national cohesion, progress and development of women in any nation. Therefore, efforts must be made to address the very important issue associated with women's emancipation for socio-economic transformation. The support for women's emancipation is very germane in the $21^{\text {st }}$ century for national development and transformation. Therefore, it should be vigorously canvassed.
\end{abstract}

Keywords: Emancipation, Gender, Socio-economic, Transformation, Women

\section{INTRODUCTION}

The position of women in society in relation to men and the subordination, oppression and marginalization of women has attracted the attention of scholars, activists, feminists and development workers for a very long time. Historical evidences in many societies, both during the ancient and modern periods support the idea of male domination over their female folks in many spheres of human endeavour (Aina, 2012). The literature on the subjugation of women to men's domination knows no bound with such literature covering wide range of issues, including the body, class and work, disability, the family, globalization, human rights, culture, race and racism, reproduction, science, the self, sex, work, human trafficking and sexuality (Nkoyo, 2002). The issues relating to what is also known as gender inequality has become very prominent in the last few decades. It has a great impact on policy making and implementation. The United Nations has programs and agencies like Commission on the Status of Women has been responsible for organizing and following up the world conferences on women in uplifting the status of women in political affairs and socio - economic development. Past conferences such as Mexico (1975), Copenhagen (1980), Nairobi (1985) and the recent one Beijing (1995) in China, with the theme "Equality Development and Peace Contriving Strategies" towards active liberation and empowerment of women with its overall aim at annulling those practices and values that discriminate against women; taking steps to increase the number of women representation in legislative bodies around the world. Nigeria has achieved little progress in this regard. 
The slow progress with women's political representation in Nigeria is intimately connected with how the problem of women's underrepresentation is perceived and understood as well as the strategies adopted to address it. Traditionally, in Africa and particularly in Nigerian culture and history, women have been involved in politics and socioeconomic development in governance but the level of participation is low when compared to the level of males. Having tasted political power and found it appealing, the male gender continued to consolidate its position by fencing out their female counterparts from the mainstream political activities where the real power lies. At best, women were strategically, through several means including cultural exclusion, reduced to the second fiddle offices of 'deputy' and 'vice' ((Awofeso \& Temitayo, 2014).

In Nigeria, currently there are 469 legislators in the national assembly. 109 and 360 in the senate and house of representatives respectively. Out of this, only seven women are in senate while 22 are in the house of representatives. Thus, female law makers constitute $6.2 \%$ while male legislators stand at 93.8\%. At the state assembly level, there are 51 women out of 990 members, representing $5.2 \%$ in terms of representation. Therefore, this paper examined dimensions of gender inequality and discrimination that excludes women from socioeconomic and political activities. This is detrimental to national cohesion, progress and development of women in Nigerian society and beyond in the 21st century.

\section{WOMEN EMANCIPATION}

Women emancipation is the effort to secure equal rights for women and to remove discrimination from laws, institutions and behavioural patterns. Some women reformers rights movement began in the nineteenth century with the demand for women's right to vote, they advocated for the same rights as men. Many other scholars including Agbalajobi (2010) and Soetan (2014) have unveiled the travail of the female gender humiliation, manipulation and marginalization through a number of culturally biased norms and practices which has culminated into systematic institutionalization of male superiority over the female in all spheres of life - socio-culturally, economically and politically. Indeed, the life circle of a woman from the cradle to the grave is said to be characterized by all manners of violence related to manipulation and control of women by men through sex selective, abortion, different access to medical care, incest and sexual harassment in the workplace, rape, marital rape, abuse of widow, etc

By the virtue of the population of Nigeria, the potential female labour force is $50 \%$ but the actual value is $31 \%$. The proportion of women in the formal sector is very minimal. This is noticeable in the industries and the civil services; statistics indicate that in the Federal Civil Service, which the highest employer in the country is, women are mostly found in the junior categories (Ajir, 2002). Women are mainly involved in petty trading, selling wares in the market and street hawking in urban areas. According to statistics $78 \%$ of women are mostly engaged in the informal sector, which are farming and petty trading. Despite this, their contribution is not commensurate monetarily. The women's unpaid labour is twice that of men, and its economic value is estimated to be up to $30 \%$ of the nation's Gross National Product. Women self-advancement has been curtailed by the burden of reproduction, particularly in Nigeria with a very high birth rate as well as the cultural roles associated to women - role of child bearing, child raising and homemaking.

Literature is however replete with numerous practice of the tenet of Affirmative Action. For example, in the United States of America, obvious references are made in respect to government policies on preferential admissions of women into higher institutions of learning. This is to foster the spirit of self-determination and class consciousness (Ihonvbere, 2000; Orji, 
2003). The tendency also is to more or less in corporate women into mainstream corporate governance and sense of worth, liberty and freedom.

Similarly, the scope is less pervasive in Germany. However, what exists can be said to be related to the use of legal measures to ensure factually equal positions for women and men in professional life. Again, in Uganda, certain parliamentary seats are reserved for women in the 39 districts, and in Argentina the electoral laws establish as a point of responsibility the rights of women as specific quotas are allocated and considered and exclusive pressures of the women class. The same case holds true of countries like India, Eritrea, Bangladesh and Iran of recent.

The past two decades have witnessed an impressive rise in women's political representation around the world, with the global average in the share of women in national parliaments doubling during that time, and all regions making substantial progress towards the goal of 30 percent women's representation in decision making. However, more progress could still be achieved. The rate of increase in the political representation of women has been fast in some African countries with four of the world's top 10 countries, in terms of women's share of single or lower house of parliament. Rwanda elected more than 60 percent (IPU, 2015). Since 2003, Rwanda has maintained the record as the country with the highest female legislative representation in the world.

Tab 1 Female Representation in Some Country's Parliament

\begin{tabular}{|lc|}
\hline COUNTRY & FEMALE REPRESENTATION IN PARLIAMENT \\
\hline RUWANDA & $63.8 \%$ \\
\hline CUBA & $53.2 \%$ \\
\hline BOLIVIA & $53.1 \%$ \\
\hline MEXICO & $48.2 \%$ \\
\hline ICELAND & $47.6 \%$ \\
\hline GRENADA & $46.7 \%$ \\
\hline NAMIBIA & $46.2 \%$ \\
\hline SWEDEN & $46.1 \%$ \\
\hline NICARAGUA & $45.7 \%$ \\
\hline COSTA RICA & $45.6 \%$ \\
\hline SEYCHELLES & $43.8 \%$ \\
\hline SOUTH AFRICA & $42.7 \%$ \\
\hline ECUADOR & $41.6 \%$ \\
\hline FINLAND & $41.5 \%$ \\
\hline AMERICA & $30.3 \%$ \\
\hline EUROPE & $26.5 \%$ \\
\hline SUB-SAHARAN AFRICA & $23.8 \%$ \\
\hline ASIA & $19.7 \%$ \\
\hline ARAB STATES & $18.7 \%$ \\
\hline NIGERIA & $6.2 \%$ \\
\hline
\end{tabular}

HIGH

AVERAGE

LOW

Source: Inter-Parliamentary Union 


\section{PARLIAMENTARY ACT ON FEMALE REPRESENTATION}

The representation on the people Act of 1918 was an Act of parliament passed to reform the electoral system in Great Britain and Ireland. The Act gave the right to vote to women at age of 21 regardless of any property qualification, which added another 5 million women to the electorate. Widened suffrage by abolishing practically all property qualification for men and by enhancing women over 30 who met minimum property qualification. The enhancement of this latter group was accepted as recognition of the contribution made by women defence workers. However, women were still not politically up to men who could vote from age of 21 . Full electoral equality was achieved in Ireland in 1992, but did not occur in Britain until the representation of people equal franchise Act of 1928.

The terms of act were:

1) All men over 21 gained the vote in the constituency where they were resident. Men who had turned 19 during service in connection with world war 1 could also vote even if they were under 21 , although there was some confusion over whether they could do so after being discharged from service. The representation of the people Act 1920 clarified this in the affirmative, albert after the 1918 general election.

2) Women over 30years old received the vote, but only if they were registered property occupiers or married to a registered property occupier.

3) Some seats were redistributed to industrial towns.

4) All polls for election to be held on a specific date, rather than over several days in different constituencies as previously.

5) The act added 8.5 million women to the electorates as well as 5.6 million men. It was therefore the greatest of all electorate reforms Act in terms of electorate addition.

Politically, the size of the electorate tripled from the 7.7 million who had been entitled to vote in 1912 to 21.4 million by the end of 1918 . Women now accounted for about $39.64 \%$ of the electorate. Had women been enfranchised based upon the same requirements as men, they would have been in the majority because of the loss of men in the war. The age of 30 was chosen because it was all that was politically possible at the time. Any attempt to take it lower would have failed.

The Act lays the foundation for other international commitments in the area of women's rights. The 1948 Universal Declaration of Human Rights (UDHR) enshrines "equal rights of men and women", including the right to participate in government. The 1979 United Nations (UN) Convention on the Elimination of All Forms of Discrimination against Women (CEDAW). The 1995 UN Beijing Declaration and Platform for Action expanded CEDAW. Provide opportunities for women and men to participate equally in all political processes is a human rights obligation, and that respect for these rights brings greater democratic legitimacy and increases the likelihood of inclusive governance. Similarly, the United Nations Millennium Declaration, adopted in 2000, known as the Millennium Development Goals (MDGs) - with related targets, which constitute an international agenda for the twenty-first century. In it, UN Member States agreed to "promote gender equality and the empowerment of women as effective ways to combat poverty (UDHR, 1948; CEDAW, 1979). To achieve gender equality and empower all women and girls, these international obligations, standards and instruments are germane for the advancement of increased women's representation in political leadership position

\section{WOMEN'S SOCIOECONOMIC STATUS IN NIGERIA}

Nigerian women, like their counterparts, around the world, face a lot of discrimination that limit their opportunities to develop their full potential on the basis of equality with men. They are far from enjoying equal rights in the labour market, due mainly to their domestic burden, 
low level of educational attainment, poverty, biases against women's employment in certain branches of the economy or types of work and discriminatory salary practices. In some establishments women are not allowed to get married or pregnant because it is thought that it will reduce their productivity and of course profit. Some women particularly the young ones are only employed as long as they are ready to use their bodies to woo customers for their business organizations. This is what is called corporate prostitution. In fact, women are faced with a lot of challenges in the society as displayed in the Figure 1 below

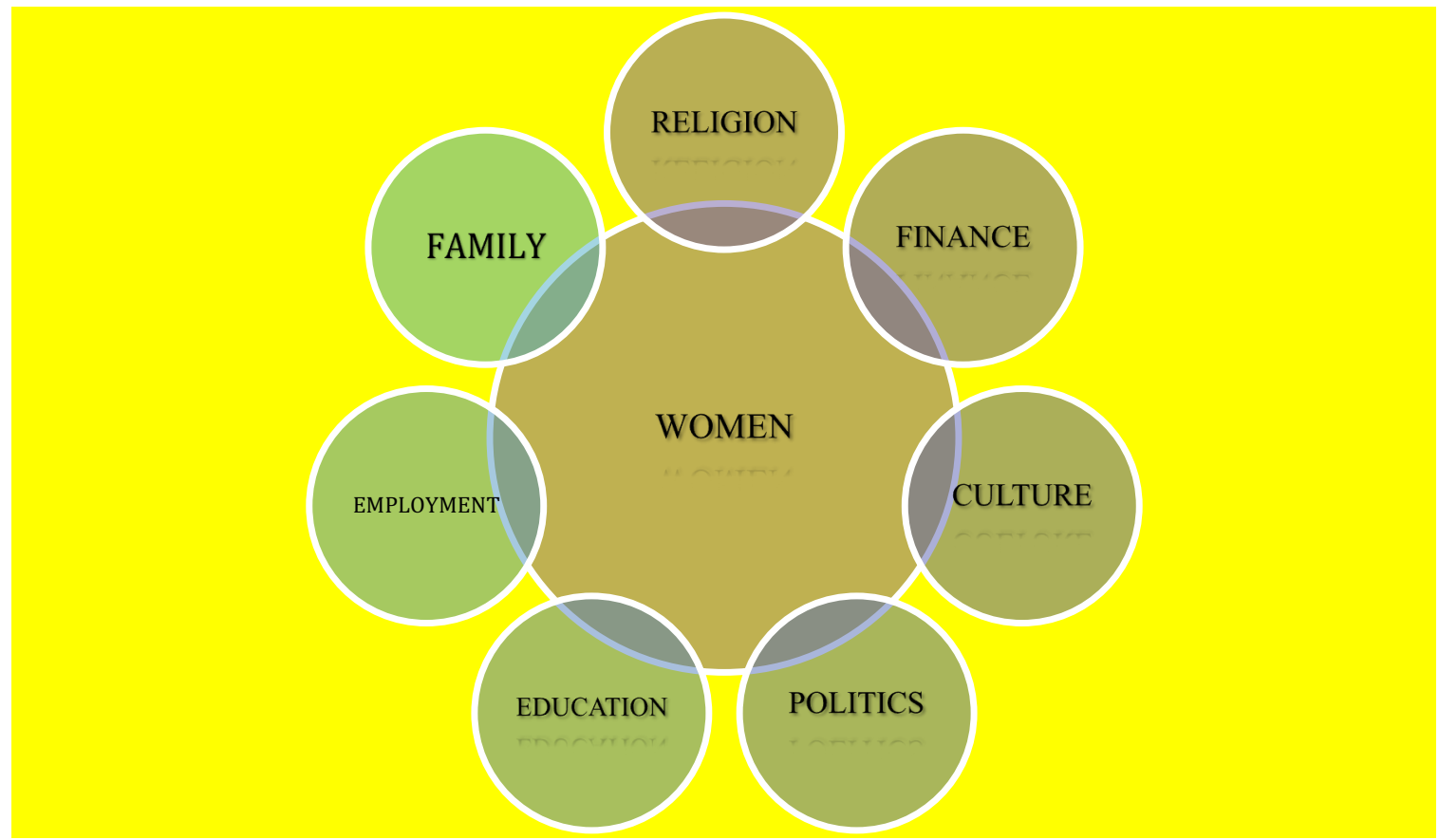

Fig 1. Some Factors That Affect Women Participation

Women are mostly involved in farming and food processing. They do not have access to land but can only use the land at the benevolence of their husbands and brothers. Women also have limited access to agricultural inputs. Women tend to be disadvantaged, because when compared with men, they do not have access to obtaining credit facilities and so are rarely engaged in the production and marketing of lucrative cash crops, such as cocoa, which tends to be a male preserve. The legal protection granted by the constitution and the Labour Act has little or no effect in the informal sector - agriculture and domestic services where the vast majority of women are employed. Nevertheless, Nigerian political parties could enhance women participation in Nigerian politics. The review of the relevant sections of the constitution must as a matter of necessity; include the plight of women in the scheme of things to forestall future discrimination of Nigerian women in politics and other spheres as well. However, it is worthy to note that while some African countries are making giant strides in women's political representation, others like Nigeria have achieved very little progress.

Table 2: Women In Nigerian Parliament

\begin{tabular}{|c|c|c|c|c|c|c|c|c|}
\hline \multirow{2}{*}{$\begin{array}{l}\text { World } \\
\text { Ranking }\end{array}$} & \multicolumn{4}{|c|}{ House of Representatives } & \multicolumn{4}{|l|}{ Senate } \\
\hline & Elections & Seats & Women & $\%$ & Elections & Seats & Women & $\%$ \\
\hline 181 & 03.2015 & 360 & 20 & 5.6 & 03.2015 & 109 & 7 & 6.5 \\
\hline 125 & 04.2011 & 360 & 24 & 6.8 & 04.2011 & 109 & 7 & 6.4 \\
\hline 117 & 04.2007 & 360 & 25 & 7.0 & 04.2007 & 109 & 9 & 8.3 \\
\hline 107 & 04.2003 & 360 & 17 & 4.9 & 04.2003 & 109 & 3 & 2.8 \\
\hline 104 & 02.1999 & 360 & 12 & 3.4 & 02.1999 & 109 & 3 & 2.8 \\
\hline
\end{tabular}

Source: Inter-Parliamentary Union, “Women in National Parliaments” 


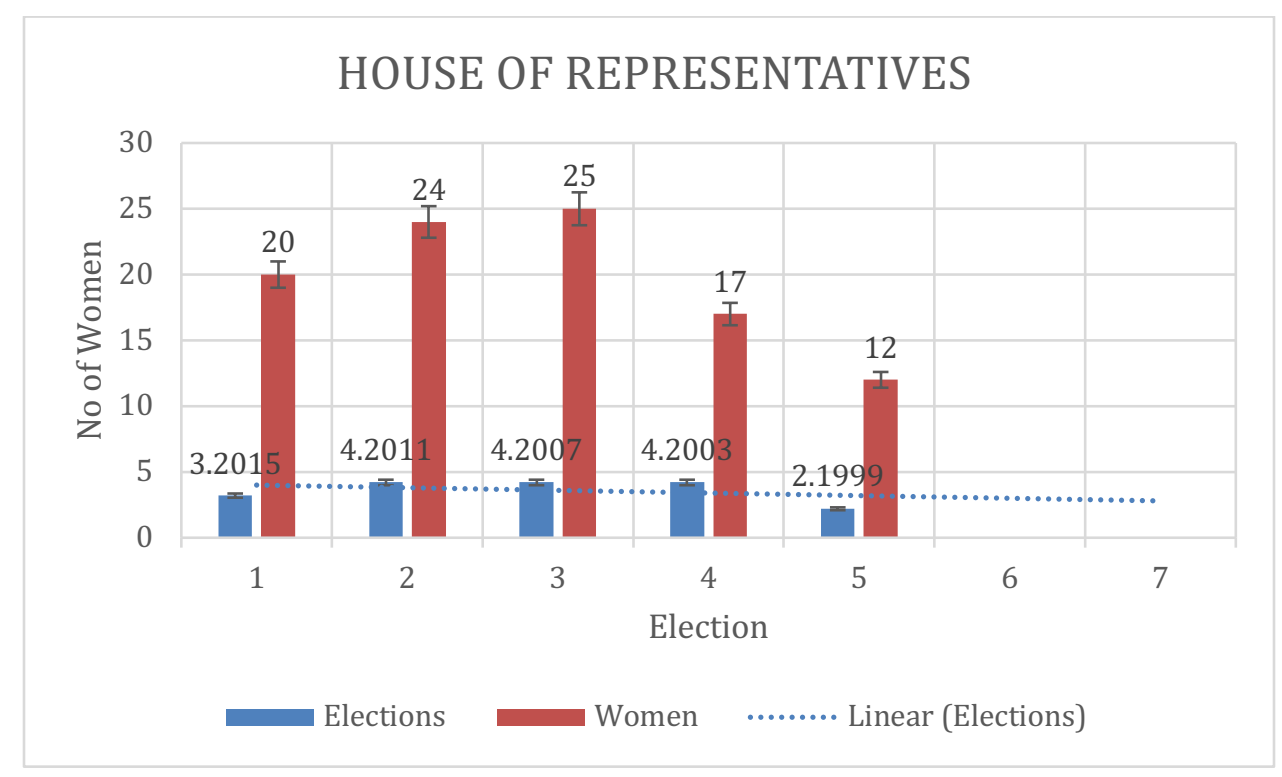

Fig 2. Source of Graph: Salako, 2019

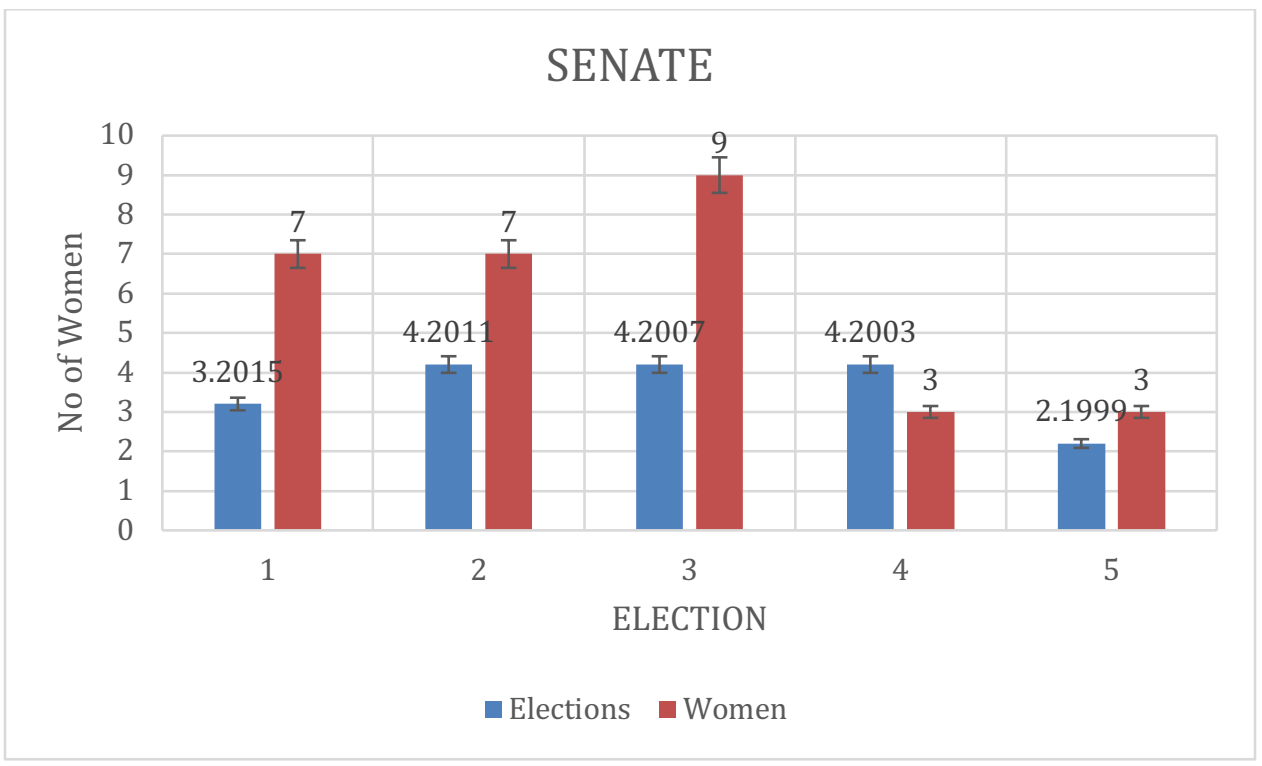

Fig 3: Source of Graph: Salako, 2019

Since 1999 when Nigeria returned to civil rule, the country has conducted five general elections (in 1999, 2003, 2007, 2011, and 2015), the just concluded result for 2019 is nothing to write home about. Women's political representation is illustrated in table 2 and shown in figs 2 and 3 revealed that Nigeria achieved the highest percentage (7.0 percent) of women's representation in the lower parliament (the House of Representatives) in 2007 after the dismal record of 3.4 percent and 4.9 percent in 1999 and 2003, respectively. However, the figures declined to 6.8 percent and 5.6 percent in 2011 and 2015. It should be noted however, that following the conclusion of a number of election petition cases by 2017, the figure went up to $6 \%$ (22 in the House of Representatives and 7 in the Senate). These show that Nigeria has made very little progress.

\section{THE AFFIRMATIVE ACTION}

The affirmative action has to do with global average in the share of women in national parliaments and all regions making substantial progress towards the goal of 30 percent women's representation in decision making. The UN also has programs and agencies dedicated in 
uplifting the status of women in political affairs, e.g. the 4th Conference of Women held in Beijing, China in 1995, with the theme "Equality Development and Peace Contriving Strategies" towards active liberation and empowerment of women with its overall aim at annulling those practices and values that discriminate against women; taking steps to increase the number of women representation in legislative bodies around the world; the improvement of women's social, economic and political status, which is essential for the achievement of both a transparent and accountable government; ensuring and encouraging the women towards realizing their abilities and utmost importance in the political and social development such that they will be significantly represented in the decision making bodies in every organization; politically educating and empowering women to take active part in the political process as party members, leaders, voter and candidates.

There is no doubt that the main beneficiaries of gender mainstreaming are petty bourgeois, middle class, elitist women who when they ascend to position as a result of long years of struggle for the participation of women insist that they made it on merit. Many of these women do little or nothing to address the women question. They are not only maintaining the status quo but also reinforce patriarchy in collaboration with men.

It is interesting to note that the principle and practice of the Affirmative Action is a universal phenomenon (Makama, 2013). Several countries of the world have history, one way or the other, showing that the rights of women and the vulnerable are to be respected and sustained. It is therefore of crucial importance for Nigeria to take a cue from best international practices in order to allow a pride of place for women. This will enhance democracy and democratic survival in Nigeria in the current dispensation and beyond.

\section{CONCLUSION}

The issue of women participation in politics has been a subject of controversy throughout the world's socioeconomic and political history. In recent years however, there has been an international struggle to secure the recognition of women as human beings who have equal rights with men. Some development experts believe that more socio-economic development will take place if women's potentials were properly tapped and utilized. The thinking that only women are suited for domestic activities is a destructive attitude that has retarded development over the years. There are very rare cases of female head of national governments in the decision-making the world over. The Nigerian experience remains more pathetic. Though Nigerian women in the majority of the number they are not adequately represented in political and even administrative positions. There is therefore a great need to engender Nigeria by dismantling the existing socio-economic status quo which hinders women participation.

Also women domestication ought to be discouraged while equal representation of all genders and social classes encouraged. Until this is done, women participation in politics will remain a mirage hence they will not be able to contribute to the development of the society be it socially, economically or politically. Government all over the world must as a matter of priority commit resources and make deliberate commitment towards women's empowerment, development and better integration into the main stream political system. Women must get up and fight, participate and even get their rights on merit and not just mere $30 \%$ concession as canvassed for at the 1995 Beijing conference in China.

\section{RECOMMENDATIONS}

The following recommendations are hereby made:

There must be a focus on girl child education in order to reduce gender gap. 
Government and non-governmental organizations should embark on the reorientation of gender equality.

Adoption of legislation and policies supporting a more gender-balanced representation.

Early marriage must be discouraged through legislation and victims punished adequately.

Educational institutions in the development of their curricula topics that centre on the general knowledge of equal rights of both sexes

The mass media should embark upon enlightenment programmes that will be based on the importance of the girl-child and the equality of both sexes

Seminars, workshops and conferences should be organized to discuss gender equality related issues.

\section{References}

Ajir, I. (2002) Women Empowerment and Work: The Challenges of the 21st Century. Abuja: ABORTS press

Agbalajobi, D.T (2010) Women Participation and the Political Process in Nigeria: Problems and Prospects. Africa Journal of Political Science and International Relations. Vol. 4 (2), Pp. 075-082. Available Online at http://www.academic Journals.org/ajpsir. Retrieved Online on the 7th July, 2014.

Aina O. I. (2012). "Two Halves make a Whole: Gender at the Grassroots of the Nigerian

Development Agenda" Being the 250th Inaugural Lecture Series Obafemi Awolowo University, Ile-Ife, Nigeria Ihovbere, J.O. 2000. Towards a New Constitutional in Africa. London: Oxford University press

IPU (Inter-Parliamentary Union). 2015. Women in Parliament: 20 Years in Review. Geneva: IPU.

Makama G. A. (2013). Patriarchy and gender inequality in Nigeria: the way forward.

European Scientific Journal vol.9, No.17 ISSN: 1857 - 7881 (Print) e - ISSN 1857- 7431

Orji, Nkwachukwu. 2014. “Nigeria's 2015 Election in Perspective," Africa Spectrum, 49(3):121-133.

Salaam, T. (2003). A brief analysis on the situation of women in Nigeria today, DSM.

Soetan RO (2014) "Economics of Inequality: Globalization, Gender and Development in

Nigeria", Being the 264th Inaugural Lecture Series Obafemi Awolowo University, Ile-Ife, Nigeria

UNESCO (United Nations Educational, Scientific, and Cultural Organization). 2008.

Education for All. Global Monitoring Report. Paris: UNESCO.

UNICEF (The United Nations Children's Fund). 2006. Women and Children: The Double DividendofGender Equality. The State of the World's Children 2007. New York:UNICEF.

Policy and Legal Advocacy Centre (PLAC) Ford foundation: www.placng.org 